\title{
Deuteronomy and Human Rights
}

G Braulik* (UP and University of Vienna)

\section{ABSTRACT}

\section{Deuteronomy and Human Rights}

If one compares the articles of the "Universal Declaration of Human Rights" dated December 10th, 1948, with the regulations of the book of Deuteronomy, one detects a surprising abundance of correspondences, or at least of similar tendencies, between them. As the social theorists of the seventeenth and eighteenth centuries, the architects of the catalogue of Human Rights, knew the Scripture very well. References to Deuteronomy are historically well probable and factually hardly coincidental. Deuteronomy rightly boasts about its social laws (4:8) that are unique in the Ancient Near East. The paper orientates itself to the short formula of Human Rights and at the same time to the normative basic character of each human right, as it is formulated in the first article of the declaration: "liberty", "equality", "fraternity". Each of these basic categories are concretised in terms of several Deuteronomic regulations and prove themselves to be central matters of concern within the YHWH religion. Finally, it is outlined how the connection between Deuteronomy and modern expressions of human rights might be explained, and further it is shown what actually makes up the peculiarity of biblical thinking on human rights.

\section{INTRODUCTION}

In our days, those committed to rendering our world more humane usually take the concept of human rights as their point of reference. In the intellectual history of humankind, the basis for human rights is found in the first instance in the doctrine of natural law and in humanist schools of thought such as the Enlightenment. However, if one compares for instance the articles of the Universal Declaration of Human Rights (HR) of 10 December 1948 with the stipulations of the Book of Deuteronomy, one finds surprisingly many correspondences or at least common tendencies. I

*Prof Georg Braulik (Professor in Old Testament at the Catholic Theological Faculty of the University, Vienna) is a guest Professor in the Departments of Biblical Studies and Old Testament, University of Pretoria during September 1998. 
propose to enumerate briefly those human rights articles which come into question and to refer to certain deuteronomic statutes to which they are directly or indirectly related:

Art. 1: Liberty, equality, fraternity - this brief formula of human rights will serve as a fundamental model for all further analysis.

Art. 2: The prohibition of discrimination - regarding women, ef Deut. 15:12; 22:13-19; regarding an escaped slave, 23:16ff; regarding aliens and former enemies, 23:8ff.

Art. 3: The right to life and liberty - cf Deut. 5:17; 18:10;22:8; 27:24ff (life); Deut. 15:12; 23:16ff (liberty).

Art. 4: The prohibition of slavery and of the slave trade - new ideas penetrate the deuteronomic legislation and there are considerable changes in practice, cf Deut. $5: 14 ; 15: 12-18 ; 16: 11,14 ; 23: 16 \mathrm{ff}$; concerning the slave trade, cf Deut. $21: 14 ; 24: 7$.

Art. 5: The prohibition of inhuman and degrading punishment - cf Deut. 25:3.

Art. 6: The entitlement to be recognized as a person before the law - cf Deut. 1:16ff; 16:18sq; concerning slaves, cf 15:16.

Art. 8: The entitlement to an effective remedy against violations - cf e $\mathrm{g}$ Deut. 17:8-13; 19: 16-21 (as a realization of 5:20).

Art 10: The right to a public hearing by an impartial tribunal - cf Deut. 1:16ff; 16:18-20; 17:8-13; 19:16-19.

Art. 11: Conviction only after guilt has been proved and only according to a law that was in force at the time when the act was committed - cf Deut. $13: 15 ; 17: 4,6 ; 19: 15 ; 24: 16$.

Art. 12: Protection of the privacy of the individual - cf Deut. 15:12-18; 23:16ff; 24:10ff.

Art. 13: The right to choose one's residence freely - according to Deut. 23:17 even for the escaped slave.

Art. 14: The right to asylum - cf Deut. 19:1-10; 23:16ff.

Art. 16: Freedom to marry and protection of the family - cf Deut. 21:1013 ; $25: 5-10$ (freedom to marry); Deut. 5:18; 15:12-15 (as an amendment to the older provision in Ex 21:2-4); Deut. 22:22; 23:1.

Art. 17: Protection of property - cf Deut. 5:19, 21; 19:14; 22:1-3; 24:6.

Art. 18: Freedom of conscience and religious liberty - for aliens, cf Deut. 14:21. As 29:9-14 makes clear, slaves are not forced to observe the law, and thus follow the religion of their Israelite masters.

Art. 22: The right to social security - cf Deut. 14:27, 28f; 15:1-6, 7-11, 12-18; 23:25f; 24:10-13, 19, $20 \mathrm{ff}$. 
Art. 23: The right to just and equitable remuneration - cf Deut. 24:14ff.

Art. 24: The right to rest and leisure - cf Deut. 5:14.

Art. 25: The right to social protection - cf Deut. 5:16; 10:19; 15:4, 7- 11; $16: 11,14 ; 18: 1-8 ; 22: 4$.

Art. 28: The right to an equitable social order - cf Deut. 4:8.

Art. 29: Duties towards the community, which alone makes possible the free and full development of the human personality - Deut. 6:20-25.

In addition, it should be stressed that the human right to happiness embodied in the Virginia Declaration of Rights (section 1) has its predecessor in Deuteronomy - for instance when a man who has recently married is exempt from military service and even from holding any public office for a year so

"that he may remain at home and give happiness to the woman he has married" (Deut. 24:5; cf 20:5ff).

Finally, the entire deuteronomic social order and the blessing it implies, is intended to ensure that:

"you, and after you your descendants prosper and that you may live long in the land that YHWH your God gives you for all time" (Deut. 4:40 and frequently elsewhere).

2 The wording of the human rights charters could, then, have been influenced by Deuteronomy. In any case, the numerous correspondences regarding the contents, as well as the fact that the social philosophers of the 17th and 18th centuries to whom we owe the classic catalogue of human rights had a good knowledge of the Bible suggest this as a possibility. Perhaps it may, one day, become possible to show by historical methods that there is a dependence. It would hardly be fortuitous. Deuteronomy is proud of its uniquely just laws $(4: 8)^{1}$. Traditio-historically, their roots go back to the period before Israel became a state. At that time, Israel constituted an acephalic segmentary society2. Its characteristic features were a great desire for liberty and an egalitarian pathos. Social relations were to a large extent determined by the "fraternal" solidarity which obtains within a family. YHWH, the god of this tribal society, the god to whom they ascribed their liberation from the Egyptian slave state and from the Canaanite feudal state, demanded a just society.

It was this ideal from Israel's beginnings that King Josiah of Judah had in mind as he reformed his state. This reform took place during the 
crisis caused by the pressure of the Assyrian cultural and political supremacy in the 7th century. The plan for a just society to which Josiah pledged the whole people in $621 \mathrm{BC}$ and which his court scribes made their measure in presenting the history of Israel forms the nucleus of the "deuteronomic law". The heading describes it as a social order "which Moses proclaimed to the Israelites when they came out of Egypt" (Deut. 4:45).

Is this claim borne out by the facts? In other words: To what extent does the deuteronomic law project into the legal sphere the historical experience of an exodus from inhuman conditions and the original vision of an equitable tribal society consisting of free and equal peasants in order to create a law and an ethos of liberty, equality and fraternity for life in the promised land? If the statutes of Deuteronomy show that such structures constitute a possible concept for social life, then they are essentially in agreement with the modern human rights charters ${ }^{3}$. True, the modern declarations derive their arguments from the nature and dignity of every human being. Nevertheless, for systematic and historical reasons ${ }^{4}$, the deuteronomic triad of "liberty", "equality", "fraternity" (or participation or solidarity) today counts as "the normative foundation of all human rights" 5 .

3 In what follows, I shall select certain statutes in Deuteronomy, in which these three fundamental rights become manifest in a tangible manner and emerge as a fundamental concern of the YHWH religion. I propose, as a general rule, to pay no attention to literary-historical differentiations, but to read Deuteronomy as a synchronic system, in the form in which it was finally accepted in the biblical canon. The narrow boundaries of our theme force us to dispense almost entirely with traditio-historical comparisons with other ancient Oriental law codes. In the section on preserving liberty (part I), I shall explore the historical preamble to the Decalogue and a version of Israel's credo. They both pledge the people to observe the ten commandments or the deuteronomic law because YHWH has brought them out of (that is, liberated them from) Egypt, the slave state. In the section on granting freedom (part II), I propose to discuss those individual precepts in which the Israelites are exhorted to remember "their" slavery in Egypt and therefore grant others their freedom in a specified way. The emphasis of my interpretation of Deuteronomy lies on these two parts. The lists of the participants in sacrifices and feasts in the section titled "Raising to Equality" (part III) are intended to illustrate where in Israel the class society was overthrown and a fundamental equality was created in spite of 
all remaining inequalities. In "Fraternity in Practice" (part IV), I shall give an outline of the ethics explicitly associated with the term "brother". Therefore, I propose to relate each of the selected laws, on the basis of the formula used or of a particular terminology, to one of the three fundamental human rights categories. However, liberty, equality and fraternity condition each other mutually and remain related to each other even in the phraseology of the individual laws. In a way, these cases even serve to illustrate the hermeneutic rule of modern human rights articles: "Every individual human right, even though it be especially close to one of the three moments, should be interpreted with regard to all three" 6 . Finally (part V), I want to give an idea of the special features of biblical thought on human rights.

\section{PRESERVING LIBERTY}

1 The Book of Deuteronomy regards its "statutes and ordinances" $(12: 2-26: 16)$ as provisions for fulfilling the Decalogue $(5: 6-21)$ that YHWH himself proclaimed on Mount Horeb? ${ }^{7}$ According to the prologue of the Decalogue, both the deuteronomic law corpus and the ten commandments are preceded by the exodus through which YHWH brought his people "out of Egypt, the slave state" (5:6). Israel did not understand this event as "principally emancipation, rebellion, change, migration, expectation" (Ernst Bloch), but as a saving act of God. Deuteronomy therefore never gives "leaving" ( $y s^{\prime}$ qal) as the reason for the commandments, but speaks - strictly theologically - of "being brought out" (ys' hi) by YHWH. (There may be one exception, 16:3). It is not simply a matter of leaving Egypt. "To bring out" is the legal expression for setting a slave free. A slave who received his or her freedom was "brought out". This liberating act on the part of God is what gives meaning to the Decalogue and to the deuteronomic law. In Deuteronomy, human rights are not grounded in a freedom which belongs to human beings because of their nature, but on an act of God which is free, based on grace and unique in history.

The Decalogue itself is not the sum of a universally valid human ethos, but thematizes "the elementary demands which have to be fulfilled if the freedom described in the prologue is to be preserved. To break one of the commandments in this catalogue of what is necessary for freedom would harm or abolish the freedom which is presupposed. Within the framework of this theme, the Decalogue strives for and achieves completeness" 8 . 
2 Israel's exodus from Egypt does not, as has already been pointed out, legitimize only the brief official formula of the Decalogue, but also the deuteronomic social order in general. In order to make this connection clear, Deuteronomy draws up its own $c r e d o^{9}$. The parents are instructed how to answer their children when, one day, the children discover the difference between their society and the nations around them and ask why the Israelites do not live as other people do. The catechetic formula is to be something like this:

"We were Pharaoh's slaves in Egypt, and the LORD brought us out of Egypt with his strong hand, sending great disasters, signs and portents against the Egyptians and against Pharaoh and all his family, as we saw for ourselves. But he led us out from there to bring us into the land and give it to us as he had promised our forefathers. The LORD commanded us to observe all these statutes and to fear the LORD our God; it will be for our own good at all times and he will continue to preserve our lives. It will be counted to our credit if we keep all these commandments in the sight of the LORD our God as he has bidden us (6:21-25)".

The exodus from Egypt is here entirely adapted to the entry into a new society. Both exodus and entry are depicted with the emancipation of a slave as a model. The person who "brought out" a slave, that is, according to the particular meaning of this expression, emancipated him or her, became the slave's new master. He could "bring him into" his house. This legal term refers to the slave becoming the property of the new master.

The emancipation of Israel from its servitude in Egypt was a legal act of this kind. Israel was freed from the rule of Pharaoh in order to come under the rule of YHWH. The sovereignty of this God abolished human sovereignty. This will emerge even more clearly later on. In any case, in Deuteronomy the formula "exodus from Egypt, the slave state" stands for a liberation brought about by YHWH. This liberation takes the form of a social order. Through this social order, YHWH establishes a society which is the opposite of the system Israel has escaped from. YHWH then brings this new society into the promised land. And there liberty means: life in plenitude in a society that has finally become just.

Our "nutshell credo" (6:21-25) gives the following explanation of the deuteronomic human rights: They are not granted to the individual in a kind of individualistic isolation but only within the new society which God himself has founded. The "we" or "us" which can be spoken by the whole 
community 10 constitutes the freedom aimed at. From the very beginning, this freedom has a politico-theological dimension. Furthermore, justice ${ }^{11}$ is possible only if Israel understands its social order (and the human rights contained within it) as divine right and implements this order in its social life (cf HR 28ff).

\section{GRANTING FREEDOM}

1 After delivering Israel from foreign domination in Egypt, YHWH brought his people into the promised land, which became a space for freedom. In the deuteronomic Decalogue, however, he obliged his people exiled in foreign Babylon to keep the Sabbath ${ }^{12}$ free from work (cf HR 24). During the exile, the sabbath became the one decisive sign of faith. Yet even before Israel became a state, there was a day on which work was forbidden:

"For six days you shall work but on the seventh day you shall cease work; even at ploughing time and harvest, you shall cease work" (Ex 34:21).

This life cycle is an original creation of the YHWH religion and implies a social revolution. Its seven day rhythm breaks with the course of the month and the year, even when - as at ploughing or harvest time - the natural order as well as economic necessity make continuous work seem reasonable, even unavoidable. Israel does not owe its (agrarian) life to the mythic power of the earth but to have been freed by God from all systems of exploitation and oppression. Even in the old cultic Decalogue, the seventh day probably constituted a powerful sign of Israel's exodus freedom (cf Ex 34:18). At any rate, the deuteronomic Decalogue grounds the periodic rest from work in the exodus event:

"Remember that you were slaves in Egypt and the LORD your God brought you out with a strong hand and an outstretched arm, and for that reason the LORD your God commanded you to keep the sabbath day (Deut. 5:15)".

The parenesis associates (but only in this passage in Deuteronomy ${ }^{13}$ ) the memory of Israel's bondage in Egypt with the exodus. In Deuteronomy, the formula first used - "remember that you were slaves in Egypt" - is reserved for cultic laws with social and charitable contents and for social 
laws which concern those living on the margins of society: male and female slaves $(5: 15 ; 15: 15 ; 16: 12)$, aliens, orphans and widows $(24: 18,22$; cf $10:(18-) 19 ; 23: 8)$. The exhortation to think back to the slavery they had themselves suffered under was intended to strengthen the free Israelites in their decision to grant freedom to those who were economically dependent. We shall go on to examine all the laws concerned.

In this context, it is important to realize that even the sabbath commandment demands such a liberating practice. In addition, this commandment refers back to the exodus from Egypt, which the prologue has made the presupposition for the whole Decalogue. However, the sabbath commandment, unlike the other Decalogue commandments, does not merely preserve the freedom YHWH has granted to the Israelites. It demands that even people who do not belong to those "freed from the slavery in Egypt" (to whom the prologue is addressed) be granted freedom by being granted free time.

Of old, Israelite law differed from current practice elsewhere in antiquity by not sharing out leisure and work according to social status, granting leisure to the well-to-do and making the underprivileged work (Ex 23: 12). In the deuteronomic sabbath commandment, this restructuration of the social system takes its place in the literary and theological centre of the Decalogue. This is not the case for the parallel in Exodus 20:8-11. Furthermore, the sabbath commandment in Deuteronomy differs from the version in the Book of Exodus in several details ${ }^{14}$ in order to stress and support the social and humanitarian concern for the right to rest and leisure. In both texts, the sabbath removes the class distinctions between the workers in a "family workers" pool". It is evidently because of the shattering impact of this provision that we are given a list of those who have the right to a day of rest. The list shows changes which are slight from a literary point of view but important in their effects:

"But the seventh day is a sabbath of the LORD, your God: that day you shall not do any work, neither you, your son, or your daughter, nor your male or female slaves, nor your ox, your ass or any of your cattle, nor the alien within your gates (Deut. 5:14)".

The prohibition concerns a "house" as a working pool. The only "you" which is directly addressed and hence made responsible for keeping the sabbath is the free man as well as the free woman ${ }^{15}$. Then Deuteronomy puts the members of the family, the staff and the animals used for work on the same level. This is accomplished by means of $a(n)$ "(n)or" which does 
not occur in the Exodus parallel (really a "w"), of course an "or" between those who are free and those who are unfree, that is, between "son and daughter" and "male and female slaves". Among the domestic animals, the ox and the ass, who work hardest, are mentioned first and explicitly. But then all farm animals are granted the freedom of the sabbath as a matter of principle. The list ends with the alien. He or she is a worker who does not belong to the house. Yet when employed, he is in a certain way associated with the family; he is "your" alien. This distinguishes him from the other social cases, the Levite, the orphan and the widow, who are not mentioned in this list.

In contrast to the Exodus model, the deuteronomic sabbath commandment once more emphasizes:

"so that your male and female slaves may rest as you do" (Deut. $5: 14)$.

The words "as you do", which are not found in the old law of Exodus 23:12, use the extreme case of the slave to demonstrate that the right to sabbath rest is related to equality and to participation in this basic right. As in the triad of the basic human rights principles, the three aspects cannot be separated from each other. Equality and participation, however, are consequences of the freedom which has been granted and preserved. To emancipate the socially disadvantaged and show solidarity with them is demanded by the memory of Israel's bondage and of the exodus event brought about by YHWH. Thus argues the final substantiation of the law $(5: 15)$ which has already been cited.

Anyone who has known the hardships of forced labour and then become a full member of society ought to be capable of empathy with those who are in a similar situation and ought to understand that they need rest. He or she ought to feel solidarity with them and therefore to develop a strategy for changing such alienating structures. However, Deuteronomy does not merely make a psychological appeal to the experience of the Israelites; the most important thing is the theological reference to YHWH as redeemer. If free Israelites allow the unfree members of their household to participate in their own lot, they do not merely accept these as their equals but also, by emancipating them, act in a way resembling God's. In the last analysis, the sabbath commandment goes back to YHWH as legislator. Thus it is ultimately YHWH's supremacy which grants human rights to those who have no rights and which protects these rights as being divinely instituted. Furthermore, YHWH's supremacy is an incitement to 
abolish the class barriers.

2 Since the earliest times, slavery was part of the socio-economic structure, even of the ius gentium of the ancient Orient. However, we must not simply identify this form of slavery with the Graeco-Roman institution and then judge it from our modern point of view. In Israel, the term 'ebed - the usual term for a slave - is not restricted to this status or this social sphere, but denotes any relation of a subordinate to his master. The 'ebed relation cannot obtain between two members of the same family. "Fraternity" is not compatible with slavery. And all Israelites are brothers, since YHWH has delivered them from bondage in Egypt in order that they may become his people (' $\mathrm{am}$ ), that is his family (e $\mathrm{g}$ Deut. 4:20). If there are nevertheless Israelite (!) slaves, this is in fact only in order to help these people socially and economically by bringing them into another family when they find themselves in distress. At any rate this is the view held by Deuteronomy.

The institution of slavery is therefore allowed to remain, but is humanized so as to take human rights into account. This emerges very clearly from the Hebrew slave law ${ }^{16}$. This law argues - as does the sabbath commandment - from the solidarity obtaining between people who have been liberated, then adds the concept of brotherhood. The first case to be discussed is that of the Israelite who, in desperate straits, gives up his independent existence and sells himself to a fellow countryman in order to pay his debts.

"When a fellow Hebrew, man or woman, sells himself to you as a slave, he shall serve you for six years and in the seventh year you shall set him free. But when you set him free, do not let him go empty-handed. Give to him lavishly from your flock, from your threshing floor and your wine press. Be generous to him because the LORD your God has blessed you. Do not take it amiss when you have to set him free, for his six years' service to you has been worth twice the wages of a hired man. Then the LORD your God will bless you in everything you do. Remember that you were slaves in Egypt and the LORD your God redeemed you; that is why I am giving you this commandment today" (Deut. 15:12-15).

The characteristic features of the deuteronomic provision are not evident when compared to the version of the slave law found in the Covenant Book, the oldest collection of laws in the Old Testament (Ex 21:1-6). 
Deuteronomy does not take as its point of departure the needs of the buyer (as Ex 21:2 does), but the desperate situation of the person who chooses to become a slave. That person acquires legal status and dignity. The transaction is not seen as an unproblematic business deal, but as a regrettable though unavoidable exception. In a sense, it can be called the last safety net in the social welfare system of chapter 15 , and it may only be used when there is no other way of preventing economic disaster. After all, the prospective slave is "your brother, a Hebrew man or woman". The Covenant Book merely speaks of "a Hebrew slave". The term "Hebrew" does not define him as an Israelite, but as a member of a class on the lowest step of the social ladder, which constituted a cheap labour pool. In Deuteronomy, on the other hand, "Hebrew" denotes an Israelite and a fellow citizen. When the text expressly mentions "a Hebrew woman", this is in order to guarantee the position of women as legally emancipated (cf HR 2) and as "brothers". The work to be accomplished is limited to six years' service. Since Israelite slaves were set free again in the seventh year of their bondage, the slave law of Deuteronomy is related to the year of release ${ }^{17}$. According to the Covenant Book, the slave was free to "leave" in the seventh year. Deuteronomy, on the other hand, obliges the creditor to "release" his slave (cf HR 4).

Thus Deuteronomy deliberately changes the subject of the action - in comparison to the provisions of the Covenant Book - both at the beginning and at the all-important conclusion of the contract of employment. In other words, Deuteronomy does not allow the slave to do something, but obliges his master to do something. This is typical of the deuteronomic laws with their bias in favour of the weak and the poor. The Covenant Book certainly excludes any payment on the part of the slave and obliges his owner to let him go "without compensation". However, letting him go may take the perverted form of sending him away, namely in those cases where, although discharged of the first debt, the slave is in danger of having to sell himself once again. It was precisely from this risk that the Israelites had to be protected. Whereas the Covenant Book simply determines what belongs to the released slave and what belongs to his former master (Ex 21:3f), Deuteronomy therefore firmly enjoins the master to ensure that his slave is in a position to establish himself as an independent member of society (HR 3 ). When the moment to release him comes, the slave must be "liberally furnished" with livestock, corn and wine. The literal meaning of this expression, which is only used once more in the Old Testament, is "to put a necklace round someone's neck". (Ps 73:6). It is not, then, a matter of "dispatch casuistry" - it would in fact be quite impossible to bring away the 
foodstuffs mentioned in the way described! - but of honourable provision and of treating the former slave with dignity.

It is hard to find a legal justification for this kind of social rehabilitation and economic integration, but there is certainly a theological justification. To begin with, it is a question of participating in blessings received from God. And that is the standard used. Ultimately, however, such freedom - not simply "release" - is granted because YHWH "has redeemed the Israelites who were slaves in Egypt". To "remember" is to allow those Israelites who are now slaves to participate in this freedom, since they are "brothers". The final consequence of this would be to abolish the very institution of slavery.

If this institution is still allowed to exist, it is only as a way out for those who need it in order to survive. Indeed, Deuteronomy sees it as a possibility to give not only economic, but also all-embracing human assistance. This can be concluded from the following subsidiary case. In spite of all fidelity to principles, no authentic human relationship may be destroyed, even if it originated in slavery. The free decision of the slave must be respected (cf HR 6) if he explains:

"I do not wish to be released by you"

And the text goes on:

"because he loves you and your family since he fares well with you then you shall take an awl and pierce through his ear to the door and he will be your slave for life. You shall treat a female slave in the same way" (Deut. 15:16f).

In contrast to the Covenant Book (Ex 21:5), the slave's wish to remain is not determined by his love for his wife and children, who would remain the property of his master after his release, but solely by the fact that he had been well treated, was content with his lot and wanted to continue living in this way. In a symbolic act, he becomes a bondman forever by being nailed to the house in which he wishes to remain. His right to happiness takes precedence over every ordained release (cf the Virginia Bill of Rights, section 1). In some cases, being released from slavery could mean social degradation, namely if the former slave could not establish himself as an independent member of society, but had to live an insecure life as a day labourer. Deuteronomy deliberately leaves out those passages of the Covenant Book which concern the wife and children of someone 
who has sold himself as a slave (Ex 21:3f). According to Deuteronomy, a slave's family also enjoys protection from being seized (cf HR 16). Even a slave's private life and intimate sphere were to remain free: he had "sold" his working capacity, not his person. It is not, therefore, a coincidence that the deuteronomic slave law avoids the title of master: both male and female slaves are "brothers".

We can thus establish that the law concerning debt slavery, like the sabbath commandment, contains the triad of the human rights principles. It is, however, fraternity which restores those who have been redeemed by YHWH to freedom and renewed equality. Even within the institution of slavery, this notion transforms the structures of oppression into a loving and happy life together.

3 If, however, a master exploited and oppressed his slave, the slave could escape by flight. Deuteronomy supports him in this. It does not defend the claim of the slave owner, but the human rights of the slave. The law which was to be applied in such a case can only be hypothetically reconstructed. It was probably elaborated later and given a new meaning ${ }^{18}$. The original rule is likely to have been:

"You shall not surrender a slave who seeks protection from his master with you to that master (Deut. 23:16)".

Such a protection is contrary to the entire ancient Oriental legal tradition. Israel's experiences in Egypt are not here given as the reason for the statute. However, the verb nsl nif"al, which is here used for "seek protection, save oneself", is a keyword for the redemption ( $n s l$ hi) of Israel from the power of the Egyptians ${ }^{19}$. By using this term, Deuteronomy could therefore suggest that the protection offered by an Israelite to a runaway slave could be compared to the redemption to which Israel owed its freedom. There are no conditions attached to this reception. The slave alone decides whether he or she is to remain a slave or not (cf HR 12). Thus the institution of slavery is in practice abandoned as soon as it has ceased to fulfill its function as a form of social assistance.

This slave law later developed into a right to asylum for foreign refugees, independently of their social position (cf HR 14). The old law of 23:16 was reinterpreted by the addition of verse 17 . This addition reads as follows: 
"Let him (the escaped 'ebed) stay with you anywhere he chooses in any of your settlements, wherever suits him best. You shall not force him".

In this context, 'ebed (23:16) means anyone in a subordinate position'20, a minister as well as a slave. "You" no longer designates the individual Israelite, but the whole people amongst whom the refugee finds shelter. The legal protection offered is unique in the whole ancient Orient. Other treaties and law codes decreed that escaped subjects had to be returned to their foreign lords. Deuteronomy does not merely refuse such a demand for extradition, but grants the refugee a higher social status. It ensures that the escaped 'ebed becomes a protected person ( $g e r$ ) in Israel, that is, a resident "alien". This probably constitutes a radicalization of a provision in the Covenant Book which decreed:

"You shall not wrong an alien or be hard upon him, for you were yourselves aliens in Egypt (Ex 22:20)".

The formula, up to now a feature of the liberation laws in Deuteronomy, at any rate belongs to the traditional background of the deuteronomic asylum law. The refugee is not interned, but may freely choose to reside where he or she likes (cf HR 3). Incidentally, otherwise Deuteronomy claims this privilege only for God. The stateless are to be fully integrated - "in your midst" 21 - and to live where they choose ${ }^{22}$. It is forbidden to exploit their legally secure but socially weak position - just as it is forbidden to exploit that of the alien.

4 The resident alien (ger) belonged to a free class. However, Israel's own past showed how precarious the position of a resident alien could become. Therefore even the Covenant Book appealed to the empathy and the Egyptian experience of the Israelites:

"You shall not oppress the alien, for you know how it feels to be an alien; you were aliens yourselves in Egypt" (Ex 23:9).

The argumentation is reminiscent of the "golden rule". This rule would have more or less the following wording: "Treat aliens as you would have liked to be treated when you were aliens in Egypt"23. The corresponding ordinance in Deuteronomy also reminds the Israelites of the common historical fate, but then moves beyond human solidarity. The solicitude for the 
alien is given a theological foundation. Israel is to imitate the love God shows to all strangers:

"(YHWH) loves the alien who lives among you, giving him food and clothing. You too must love the alien, for you once lived as aliens in Egypt" (Deut. 10:18f).

It is no longer merely that oppression is prohibited: love is demanded (cf HR 25). This love gives the alien what he needs for his livelihood and thus protects him from economic pressure which could all too easily end in slavery. Both participation and freedom are here founded on the fundamental equality of Israelites and aliens before God: both are in need of his love and his blessing, which he gives - unconditionally. Not even the former slave owners are to be excluded (cf HR 2):

"The Egyptian shall not be an abomination to you, for you were aliens in his land. The third generation of children born to them may become members of the assembly of the LORD" (23:8f).

5 Charity does not dispense from justice. Aliens had a legally defined position. In fact, however, they - like other members of the lower classes had difficulty in obtaining justice against those who had more social and economic power. Therefore Deuteronomy demands, concerning these people who may be in extreme need of protection:

"You shall not deprive aliens who are orphans of justice. Remember that you were slaves in Egypt and the LORD your God redeemed you from there; that is why I command you to do this" (Deut. 24:17f).

Origin, social position, sex, or even religion are not to determine whether the law is to have force. Precisely Israel must accept equality before the law (cf HR 7). The Israelites were themselves degraded to slaves. Redeemed, they are now under the dominion of YHWH.

6 Orphans, even when they are aliens, are through their claim to justice the equals of the widows (27:19), indeed of all Israelites (16:19); they may not be deprived of justice (cf HR 7). Deuteronomy stresses this particularly in the case of aliens, orphans and widows because these people were especially exposed to judicial arbitrariness. They did not belong to a 
family and usually did not own property, which meant that they had neither influence at the local court of justice nor sufficient means. Deuteronomy therefore unites aliens, orphans and widows in a from now on proverbial triad of people in need of assistance and entrusts these social cases to public welfare. In order to guarantee their livelihood (cf HR 22), Deuteronomy establishes a kind of social security. Every third year, the tithes which were formerly delivered to the Temple are to be stored in the locality so:

"that the aliens, orphans and widows in your settlements may come and eat their fill" (Deut. 14:29; cf 26:12).

This welfare institution is extended by the right to gleaning which Deuteronomy grants these three groups $(24: 19,20 \mathrm{ff})$. In this context, Israel is once more reminded of its former existence in slavery (24:22). As long as there are the "poor", Israel is, in a certain manner, still in the same situation as in Egypt and during the exodus. On the margins of Israelite society, this insecure existence was repeatedly re-experienced. For Deuteronomy, general prosperity is not a social utopia, but something which God demands. In the middle of the law concerning the remission of debts in the sabbath year, which aims at liberating the whole people from poverty, we find the following fundamental affirmation concerning the society of Israel:

"But there should be no poor among you, for the LORD will bless you in the land, which your God gives you for an inheritance and which you take possession of".

Thus the scandal of poverty can be removed in Israel (cf HR 25). The blessing only depends on whether Israel implements its just social order (15:5 - cf HR 28f). Since this is open to question, Deuteronomy does contain "poor laws".

\section{RAISING TO EQUALITY}

In spite of all social differences which still obtain in Israel, there is one occasion on which the status and class society has already been overcome in its very foundations: the feast $(16: 9-12,13-15)^{24}$. Because Israel constitutes a single family - the "family" ("am) of YHWH - the Israelites celebrate their feasts together in one single sanctuary. When they hold a 
meal together and rejoice before YHWH, that is, in mystical union with their God, there can no longer be any divisions. All the needy and dependent are to participate in a harvest blessed by YHWH. The deuteronomic cult order, otherwise very restrained in the matter of cultic rubrics, goes further than the old festival calendar (Ex 34:22; 23:16) and defines the group of participants. The festival community is based on the family; that is, it is not formed from above but, so to speak, constructed from below. The following are to be invited:

"You (that means the free man as well as the free woman) shall rejoice before the LORD your God, with your sons and daughters, your male and female slaves, the Levites who live in your settlements, and the aliens, orphans and widows (those who are not in a position to form a festival community) who live among you (and who are therefore neighbours)" - (Deut. 16:11; cf 16:14).

We have already found a similar list in the sabbath commandment of the Decalogue (5:14). Other comparable catalogues determine who is to enjoy the sacrificial meal $(12: 7 ; 12: 18)$, tithes $(14: 26 \mathrm{f}$.) and first produce $(15: 20$; 26:11). The underprivileged are not merely to be able to rest "as you do" (5:14). They are also to taste their equality. Why does the joy of the festival reach its culmen only when all are together? There can be only one reason for this: "Remember: You were yourselves slaves in Egypt" (16:12).

\section{FRATERNITY IN PRACTICE}

1 Israel has been liberated in order to live a fraternal life ${ }^{25}$. In Deuteronomy, the word 'ah, which is usually translated "brother", does not specify the sex of a person; it includes women (15:12). The deuteronomic ideal of brotherhood has associations with the time before Israel became a state. Through the exodus from Egypt, the slave state and from the oppressive systems of the Canaanite city states, Israel emerged as a tribal society. During the monarchic period, this fraternal Israel was gradually transformed into a stratified society. The deuteronomic law attempts to reform this state by emphasizing the original equality of all Israelites. In this way, it permeates the entire social system with fraternal structures. And it goes much further than the older Covenant Book, in which the term "brother" never occurs.

Deuteronomy does not abolish the king. But it teaches him "not to raise his heart above his brothers" (17:9). The disgrace of the stratified 
society is attacked where it had its beginnings. In addition, Deuteronomy outlines a state in which the powers are separated instead of a hierarchic state. Through the fraternal relation, the laws regarding public offices abolish every distance between "superior" and "inferior" members of society. Thus judges are to treat every litigation among their brothers (1:16). Both king (17:15) and prophet (18:15) come from the midst of their brothers. The priestly tribe of Levi is to live among the Israelites, their brothers (18:2). The Levites who live in the country have the same rights as their levitic brothers who are employed at the temple of Jerusalem, the principal sanctuary (18:7-8).

2 The notion of fraternity transforms the other end of the social scale as well. It comes into effect in 15:1-18 when those who, in various ways are unfree, are liberated. Later, some of the humanitarian provisions in 1925 again make use of the term "brother". In the liturgical sphere, the language of brotherhood does not occur: in this sphere, the class distinctions have already been overcome.

The ethics of brotherhood is, as we were able to determine from the law concerning Hebrew slaves, a consequence of the liberation of Israel by YHWH (15:15). However, the YHWH family will truly become a people of brothers and sisters only when every single Israelite recognizes his needy neighbour as his brother and treats him accordingly $(15: 2,7$ - cf $23: 20 ; 15: 12$ ). Even a personal enemy amongst one's fellow countrymen must be able to count on unselfish help because of this fraternal solidarity. True, even the Covenant Book decrees:

"When you come upon your enemy's ox or ass straying, you shall take it back to him. When you see the ass of someone who hates you lying helpless under its load, however unwilling you may be, you must give him a hand with it" (Ex 23:4f).

Deuteronomy takes up these ordinances, reinforcing and expanding them $(22: 1-3,4)$. Above all, the "enemy" is now called "brother". The word "love" is not actually used. But is this fraternal solicitude not in fact the same as love of one's enemies?

The brother must be protected from false witnesses (19:18ff), from being taken as a slave (24:7) and from being degraded (25:11). When it is a question of survival, for instance when a day labourer is not paid, then the alien - "the alien within your gates" - may claim the same rights as a poor and distressed Israelite brother (24:14f). The alien Edomites may 
even, as brothers - presumably as participants in the same cult - become members of the assembly of YHWH (23:8). Deuteronomy goes further than any "right" and makes Israel into a space where the same rules of behaviour obtain as within a family ${ }^{26}$.

\section{HUMAN RIGHTS AND JUSTICE IN THE SOCIETY OF GOD}

1 This fragmentary perusal of Deuteronomy was intended to clarify some features it shares with the human rights articles which I have mentioned at the beginning. Strictly speaking, I have only treated one aspect of my theme. The other aspect, which is at least as important, consists in all those "human rights" which Deuteronomy has formulated but which have no equivalent in any of the many human rights charters. I am thinking of, for instance, the right to celebrate feasts through which Israel lives and fulfills itself as a free society of sisters and brothers. This right can be compared to the right Christian communities have to participate in the Eucharist.

In conclusion, there are two things which still must be discussed. In the first place, how the connection we have found between Deuteronomy and the modern human rights definitions can be explained factually. Secondly, wherein the specific features of biblical human rights as transmitted by, for instance, Deuteronomy, consist.

As I remarked at the beginning, the human rights discussion was at first a product of the Enlightenment. People spoke of "fundamental rights" (for the first time in France in 1770) and of "natural rights" (1779) which belong autonomously to all human beings because of their nature and dignity. According to Deuteronomy, on the other hand, human rights are, as we have noted, theonomous and are mediated by Israel. In other words: human rights, as defined in Deuteronomy, are part of a liberation or redemption, through which God gives his people a just social order and thus brings them justice (6:21-25). This apparently irreconcilable contrast can probably be resolved both in theological and in historical terms. The authentic human face, so the Bible teaches us, can be seen only where human beings are liberated from the "worldly" societies which oppress their true nature. Only through redemption by God does human nature become itself. This history of liberation and redemption does not start with all humanity but reaches all human beings through a people chosen by God for this mission: through Israel. Even in Deuteronomy, Israel is less an ethnic and political entity than a social and religious one. In this society of God, then - later continued in the Church of Jesus - an authentically human life is possible. Only here, "human rights" can be truly recognized. 
In spite of the excellent knowledge of Scripture possessed by many of its leading men, the Enlightenment defined authentic human nature and human rights in opposition to "Christian" societies. The main reason for this was that these "Christian societies" were, at least in their basic structures, in fact largely unchristian and therefore inhuman, suppressing human rights. Yet they continued to transmit the biblical and Christian ideology. This ideology, then, was known, but had to be resisted as inhuman - because of its perversion - in the name of authentic humanity. Thus autonomous human nature became, for the Enlightenment, the point of departure for what was defined as human rights. The philosophers of the Enlightenment knew these rights from the Bible, but defined them in opposition to a Christian society which claimed to follow the Bible.

2 When we ask for specific features of biblical thought on human rights, we should put the expression "human rights" within quotation marks. We are concerned with a merely analogical concept, and this in a dual sense. As regards the element "human beings", strictly speaking, only believers are meant. For in the end, only they come into their own. Within the people of God, they are granted the liberating justice of God. As regards the element "rights" an essential aspect of ordinary "rights" must be left out of account, and that is the recourse to force. The society of God is a non-violent society. In Deuteronomy, this is expressed by the fact that human rights are spoken of above all in parenetic form and that the exodus from Egypt is given as the reason why they are to be put into practice. Other deuteronomic laws rely on sanctions in cases of human failure or evil - that is, on force, although on legally canalized force. Only the New Testament counterpart to the deuteronomic Tora, that is, the Sermon on the Mount, which also contains all essential demands contained in the modern human rights declarations ${ }^{27}$, is radically non-violent. I have restricted my study to the beginning of this way, to the deuteronomic laws as the Magna Carta of "liberty - equality - fraternity" - the very basis for modern human rights. This may demand "greater justice" precisely from us Christians and may thus lead to human rights being realized in a true sense.

\section{NOTES:}

1 See G Braulik, Weisheit, Gottesnähe und Gesetz. Zum Kerygma von Deuteronomium 4:5-8 in: G Braulik (ed) Studien zum Pentateuch (Festschrift W Kornfeld), Vienna 1977, 165-195, 187-193.

2 See the articles by $\mathrm{H}$ Engel, $\mathrm{H}-\mathrm{W}$ Jüngling and $\mathrm{N}$ Lohfink, Bibel und Kirche 38, 1983 concerning "Israel's origins". Further Chr. Schäfer-Lichtenberger, 
Stadt und Eidgenossenschaft im Alten Testament. Eine Auseinandersetzung mit Max Webers Studie Das Antike Judentum (BZAW 156), Berlin-New York 1983, 223-267.

3 We need not here discuss whether the social laws of Deuteronomy were mere Utopian models or - as I think - describe obligations which had a basis in reality and which came into effect to some extent at least in the history of Israel. For a recent view, see $F$ Crüsemann, “...damit er dich segne in allem Tun deiner Hand” (Deut. 14:29). Die Produktionsverhältnisse der späteren Königszeit, dargestellt am Ostrakon von Mesad Hashavjahu und die Sozialgesetzgebung des Deuteronomiums in L and W Schottroff (eds), Mitarbeiter der Schöpfung. Bibel und Arbeitswelt, Munich 1983, 72-103, 96-103.

4 W Ernst, "Ursprung und Entwicklung der Menschenrechte in Geschichte und Gegenwart”, Gregorianum 65 (1984), 231-270, $265 f f$.

5 F Böckle - G Höver, "Menschenrechte/Menschenwürde", NHThG 3, 95-104, 96.

6 W Huber, “Menschenrechte: Ein Begriff und seine Geschichte”, Concilium 15 (1979), 199-204, 202 (of the German edition, see the English edition for a translation).

7 G Braulik, "Die Abfolge der Gesetze in Deuteronomium 12-26 und der Dekalog" in: N Lohfink (ed), Das Deuteronomium. Entstehung, Gestalt und Botschaft (BETL 68), Louvain 1985, 252-272.

8 F Crüsemann, Bewahrung der Freiheit. Das Thema des Dekalogs in sozialgeschichtlicher Perspektive (KT 78), Munich 1983, 80.

9 See G Braulik, Sage, was du glaubst. Das alteste Credo der Bibel - Impuls in neuester Zeit, Stuttgart 1979, 26ff, 29ff; G Braulik, Gesetz als Evangelium Rechtfertigung und Begnadigung nach der deuteronomischen Tora, ZThK 79 (1982), 127-160, 137-140.

10 Verses 6:24f concerning Israel's relation to its social order are structured by the enclitic personal pronoun - $n u$, repeated seven times. Cf Braulik op cit, 1982, 139 note 38.

11 Braulik, op cit, 1982, 137-140.

12 Concerning the sabbath, see e $\mathrm{g} \mathrm{N}$ Negretti, Il settimo giorno. Indagine criticoteologica delle tradizioni presacerdotali e sacerdotali circa il sabbato biblico (An Bib 55), Rome 1973, 121-124; N Lohfink, "Die Sabbatruhe und die Freizeit”, StZ 194 (1976), 395-407

13 Deuteronomy 6:21 does relate Israel's bondage in Egypt to the exodus brought about by YHWH. The credo we have just discussed thus becomes very closely related to the sabbath commandment and to the social laws which follow. But apart from differences in syntax and wording - this verse is narrative. Cf also $15: 15$ and $24: 18$, where, however (because of the context), the redemption through YHWH is mentioned.

14 See F-L Hossfeld, Der Dekalog. Seine späten Fassungen, die originale Komposition und seine Vorstufen (OB0 45), Fribourg (Switzerland) 1982, 38-57. I cannot, however, agree with the conclusions the author draws from his observations.

15 If only the free man were addressed, this would mean that his wife, alone of all the people in the household, either had to work on the sabbath or was always, 
even on weekdays, exempt from work. In both cases, it would also follow that the free woman is excluded from all lists of the addressees of the deuteronomic laws in which she is not explicitly mentioned. In that case, she would not, for instance, travel to Jerusalem in order to participate in the sacrifice and the feast at the principal sanctuary (cf 12:18; 16:11, 14). All this is extremely unlikely, not least when we consider Deuteronomy's inclination towards the emancipation of women (see M Weinfeld, Deuteronomy and the Deuteronomic School, Oxford 1972, 291ff). At that time, women had the right to own property and could even sell themselves as debt slaves $(15: 12)$ in order to keep themselves and their families alive in case of extreme distress. Therefore the sabbath commandment must be understood to concern the work and rest of the free woman as well as of the free man - contrary to A Schenker, Der Monotheismus im ersten Gebot, die Stellung der Frau im Sabbatgebot und zwei andere Sachfragen zum Dekalog”, FZPhTh 32 (1985), 323-341, 332.

16 Concerning this matter, see primarily I Cardellini, Die biblischen SklavenGesetze im Lichte des keilschriftlichen Sklavenrechts. Ein Beitrag zur Tradition, Ueberlieferung und Redaktion der alttestamentlichen Rechtstexte (BBB 55), Bonn 1981, 269-276, 337-343.

17 On the level of the final redaction of Deuteronomy, the manumission in the seventh year is to be understood as an application of the sabbath commandment - see Braulik op cit, 1985, 259.

18 Cardellini op cit, 1981, 276-279.

19 Exodus 3:8; 5:23; 6:6; 18:4, 8-10; Judges 6:9; 1 Samuel 10:18. In Deuteronomy, nsl (hi) is found in $23: 15$, in the context of the camp law, which immediately precedes the law concerning the runaway slave.

20 Cf 1 Samuel 22:2; 25:10.

21 The expression is linked to the "alien" in Deuteronomy (16:11); 26:11; 28:43 and applies particularly to him.

22 Within the redaction of Deuteronomy which relates the individual laws to the commandments of the Decalogue, the passage 23:16f belongs to the transitional stage between the sixth commandment, which concerns sexual and family life, and the seventh commandment, which determines questions of property (Braulik op cit, 1985, 260). The slave thus finds his place between family and property. More particularly $23: 16 \mathrm{f}$ constitutes the first "commentary" on the prohibition of theft. This implies that, for Deuteronomy, "You shall not steal" means, above all, that the freedom of an escaped 'ebed is to be guaranteed.

23 Hossfeld, op cit, 1985, 48.

24 See G Braulik, "Die Freude des Festes. Das Kultverständnis des Deuteronomiums - die älteste biblische Festtheorie” in: Leiturgeia - Koinonia Diakonia (Festschrift for Cardinal Franz König). R Schulte (ed), Vienna 1980, 127-179 (especially 161-172) (in a sligthly expanded version in $T h J B(L) 1983$, 13-54, (especially 40-49). G Braulik, "Leidensgedächtnisfeier und Freudenfest. Volksliturgie nach dem deuteronomischen Festkalender (Deut. 16:1-17)", ThPh 56 (1981), 335-357.

25 See L Perlitt, "Ein einzig Volk von Brüdern. Zur deuteronomischen Herkunft der biblischen Bezeichnung 'Bruder' in Kirche”, in: D Lührmann - G Strecker (eds), Festschrift for G Bornkamm, Tübingen 1980, 27-52; G Braulik, Deuteronomium 1-16, 17 (Neue Echter Bibel), Würzburg 1986, $16 \mathrm{ff}$. 
26 I should like to point out in passing that Deuteronomy knows not only human rights, but also animal rights $(5: 14 ; 22: 1-3,4,6 \mathrm{ff})$ and even tree rights (20:19f), which are intended to preserve the environment from being damaged and exploited.

27 See for instance R Pesch, "Bergpredigt und Menschenrechte". Symposium und Akademie 30 Jahre Menschenrechte am 23. November 1978, Vienna 1979. 